\title{
Targeting IgE Antibodies by Immunoadsorption in Atopic Dermatitis
}

\author{
Michael Kasperkiewicz ${ }^{1 *}$,Enno Schmidt ${ }^{1,2}$, Ralf J. Ludwig',2 and Detlef Zillikens ${ }^{1,2}$ \\ ${ }^{1}$ Department of Dermatology, University of Lübeck, Lübeck, Germany, ${ }^{2}$ Lübeck Institute of Experimental Dermatology, \\ University of Lübeck, Lübeck, Germany
}

One major hallmark of atopic dermatitis (AD) is the elevated level of total serum IgE, which has been reported to be partly of the autoreactive type in a subset of patients. Immunoadsorption (IA) has been successfully applied in various classical autoantibody-mediated diseases such as pemphigus. Recent reports proposed the use of IA also for patients with severe $A D$ and high total serum lgE levels. In this mini-review, we summarize the current knowledge about this novel treatment approach for AD and briefly discuss the so far incompletely known role of autoreactive lgE as potential target of IA therapy in this common inflammatory skin disorder.

Rachel R. Caspi,

National Institutes of Health $(\mathrm{N} / \mathrm{H})$, United States

Reviewed by: David Voehringer, University of ErlangenNuremberg, Germany Alessandro Fiocchi, Bambino Gesù Ospedale Pediatrico (IRCCS), Italy

*Correspondence:

Michael Kasperkiewicz michael.kasperkiewicz@uksh.de

Specialty section:

This article was submitted to Immunological Tolerance and Regulation,

a section of the journal

Frontiers in Immunology

Received: 16 November 2017

Accepted: 29 January 2018

Published: 19 February 2018

Citation:

Kasperkiewicz M, Schmidt E, Ludwig RJ and Zillikens D (2018)

Targeting lgE Antibodies

by Immunoadsorption in

Atopic Dermatitis.

Front. Immunol. 9:254. doi: 10.3389/fimmu.2018.00254
Keywords: atopic dermatitis, autoantibody, IgE, immunoadsorption, inflammation

\section{INTRODUCTION}

Atopic dermatitis (AD) is a chronic or chronically relapsing, eczematous, pruritic skin disease affecting $2-20 \%$ of the general population, which can considerably affect the patient's quality of life. It is often associated with type I allergic diseases, including food allergy, asthma, and allergic rhinitis (1).

The pathophysiology of $\mathrm{AD}$ is complex and involves the interplay of genetic, immunological, and environmental factors. Both skin barrier dysfunction due to decreased filaggrin expression and a biphasic $\mathrm{T}$ cell-mediated immune reaction driven by a Th2 phenotype in childhood and acute disease phase that is shifted toward a Th1 signal in the chronic stage are considered to play important roles in the disease process. One major hallmark of the disease is the elevated level of total serum IgE in approximately $80 \%$ of $\mathrm{AD}$ patients. In fact, $\mathrm{AD}$ patients mount IgE antibody responses to various environmental allergens and autoantigens, which will be discussed later in this review (1).

The drug therapy of $\mathrm{AD}$ consists of topical emollients for barrier dysfunction and topical corticosteroids and calcineurin inhibitors for skin inflammation, as well as, in severe cases, systemic anti-inflammatory agents such as cyclosporine A. However, these conventional treatments may not show uniform efficacy and can be limited by severe side effects. Thus, several new targeting therapies, including the newly approved promising IL- 4 receptor $\alpha$ chain antagonist dupilumab, have emerged (1).

Clinical benefit has been also achieved through sequestering of free IgE by the anti-IgE monoclonal antibody omalizumab in $\mathrm{AD}$ patients with poor response to traditional therapy, although some controversial results have been reported. Effects of this treatment seem to depend on baseline total serum IgE levels as less favorable clinical responses were associated with concentrations of more that $700 \mathrm{kU} / \mathrm{L}$ compared with lower levels. This observation is based on a recent systematic review and meta-analysis of $103 \mathrm{AD}$ patients from 13 studies, which overall revealed that $43 \%$ of these patients 
could achieve an excellent clinical response after omalizumab treatment, while $27 \%$ showed satisfying results and $30 \%$ had irrelevant clinical changes or deterioration (2). Restricted clinical efficacy in some cases may be related to insufficient IgE neutralization by omalizumab, for which the recommended dosing table is limited to $150-1,200 \mathrm{mg} / \mathrm{month}(2,3)$.

In the recent years, immunoadsorption (IA) has evolved as an alternative anti-IgE treatment for patients with severe $\mathrm{AD}$ displaying high total serum IgE (4-9). In addition, it has been reported that IA can increase the threshold of IgE immunoreactivity to different food allergens and thus reduce the risk of anaphylaxis in multiple food allergy $(10,11)$. Most recently, a pilot study indicated that IA may also be used to treat patients with allergic asthma (12). While much more experience with this treatment exists in classical autoantibody-mediated diseases such as pemphigus (13), application of IA in AD is limited to only a few centers so far. The active principle of most available adsorber types is the non-specific removal of the different immunoglobulins from the patient's circulation (13), although an IgE-specific adsorber column has more recently become available (5, 8-12).

This mini-review summarizes the current knowledge about $\mathrm{IA}$ in $\mathrm{AD}$ and briefly discusses the role of autoreactive $\operatorname{IgE}$ as potential target of IA therapy in this inflammatory skin disease.

\section{IA in AD}

\section{IA Protocols}

To date, six studies on the use of IA in 2-50 patients per case series with severe $\mathrm{AD}$ and high total serum IgE levels have been published (summarized in Table 1) (4-9). The first IA treatment protocol for $\mathrm{AD}$ has been introduced by our group in 2011. In this pilot study, patients with treatment-refractory $\mathrm{AD}$ and total serum IgE levels $>4,500 \mathrm{kU} / \mathrm{L}$ were treated with a total of 10 IA on days 1-5 (week 1) and days 29-33 (week 5) by using adsorption columns that contained polyclonal sheep antihuman immunoglobulin antibodies binding the different human immunoglobulins with similar affinity (referred to as panimmunoglobulin IA) (4). The same treatment protocol was used in our two following studies, with the major difference that the adsorber consisted of monoclonal mouse antihuman $\operatorname{IgE}$ (referred to as IgE-selective IA) $(5,9)$. Three other independent studies used panimmunoglobulin IA in patients with severe AD and high total serum IgE applying (i) $1-5$ cycles of 5 consecutive aphereses at monthly intervals (6), (ii) 1 cycle of 2-4 consecutive aphereses followed by omalizumab every 2 weeks for 24 weeks (7), and (iii) 3 cycles of 3-4 consecutive aphereses at weeks 1 , 3 , and 8 (8). Some patients of the latter study were treated with IgE-selective IA (8). In all studies except for the trial combining IA with omalizumab (7), the patients' preceding topical and systemic treatments for $\mathrm{AD}$ were continued during IA therapy and modified as needed $(4-6,8,9)$.

\section{Effects on the Clinical Course}

During a follow-up time of 3-18 months, the published studies uniformly revealed a satisfactory initial linear decrease of the disease severity [measured by Scoring Atopic Dermatitis
(SCORAD) or Eczema Area and Severity Index] as early as within the first 3 weeks after initiation of IA regardless of the IA treatment protocol used (4-9). Results from our three reports indicate that IA treatment resulted in continuous and stable SCORAD improvements of up to approximately $60 \%$ for at least 3-6 months $(4,5,9)$, although some minor re-increases in the SCORAD (being still lower than before initiation of IA) were observed in patients treated by IgE-selective IA during the second half of the observation period $(5,9)$. In the study by Reich et al., clinical effects remained widely stable until 6 months of follow-up with no major differences in clinical efficacy between panimmunoglobulin IA- and IgE-selective IA-treated patients (8). Combined use of IA and omalizumab resulted in a steady decrease of the SCORAD throughout the 6-month treatment period, whereas a reverse trend was observed during treatmentfree follow-up of another 6 months (7). No additional benefit with regard to further SCORAD improvement was observed in one study when more than three monthly cycles of five consecutive panimmunoglobulin IA were applied, although one patient who completed five IA cycles exhibited a long lasting clinical benefit over 12 months (6).

Of note, the studies demonstrated that IA was associated with disease amelioration in patients' refractory to multiple conventional treatments including cyclosporine $\mathrm{A}$, which could be partly reduced or discontinued after IA $(4-6,8,9)$.

\section{Effects on Circulating IgE and Other Serum Parameters}

Results from our three reports revealed that serum IgE levels were effectively reduced by a mean of more than $90 \%$ with each IA cycle regardless of the specificity of the adsorber $(4,5,9)$. Similar IgE reductions were observed in the other three studies ranging from an average of approximately $60-90 \%$ depending on the length of the IA cycle (6-8). In contrast to panimmunoglobulin IA, however, which reduced other immunoglobulin isotypes to a similar degree $(4,8)$, serum concentrations of $\operatorname{IgM}, \operatorname{IgA}$, and IgG were decreased by only less than half using IgE-selective IA $(5,8,9)$. The concomitant decrease of immunoglobulins other than IgE by the IgE-selective adsorber is considered to be non-specific and explained by IA-related elution and dilution procedures $(5,8,9)$. Effects of IgE-selective and -non-selective IA on peripheral levels of IgE and other immunoglobulins were transient since immunoglobulin levels started to rise again following each IA procedure and precycle values remained widely similar over time $(4-6,8,9)$. Thus, considering the generally steady decrease of the disease activity following IA, total serum IgE levels only incompletely paralleled the clinical course of the patients. By contrast, a different observation was made by the combinatory use of IA and omalizumab. After initial reduction in total circulating IgE by IA, free serum IgE levels continued to fall during omalizumab treatment [in parallel with SCORAD improvement and reduction in serum levels of the biomarker thymus and activation regulated chemokine (TARC)] and started to increase again (in parallel with SCORAD worsening and increase of TARC) during follow-up after anti-IgE therapy was discontinued (7). 
TABLE 1 | Summary of published studies relating to IA and AD.

\begin{tabular}{|c|c|c|c|c|c|c|c|}
\hline Reference & $\begin{array}{l}\text { Patient } \\
\text { characteristics }\end{array}$ & IA protocol & $\begin{array}{l}\text { Concomitant } \\
\text { therapy }\end{array}$ & $\begin{array}{l}\text { Follow-up time after } \\
\text { IA start (months) }\end{array}$ & $\begin{array}{l}\text { Main clinical } \\
\text { outcomes }\end{array}$ & $\begin{array}{l}\text { Main laboratory } \\
\text { outcomes }\end{array}$ & $\begin{array}{l}\text { Side } \\
\text { effects }\end{array}$ \\
\hline $\begin{array}{l}\text { Kasperkiewicz } \\
\text { et al. (4) }\end{array}$ & $\begin{array}{l}12 \text { patients, } 3 \text { females, and } 9 \\
\text { males; 24-66 (mean 42) years; } \\
\text { SCORAD 55-98 (mean 78.6); } \\
\text { total serum IgE 4,666-86, } \\
119 \text { (mean 22,034) kU/L }\end{array}$ & $\begin{array}{l}2 \text { cycles of } 5 \text { consecutive } \\
\text { panimmunoglobulin IA } \\
\text { (TheraSorb-Ig }{ }^{\oplus} \text {, Miltenyi Biotec) } \\
\text { at weeks } 1 \text { and } 5\end{array}$ & $\begin{array}{l}\text { Topical corticosteroids/ } \\
\text { calcineurin inhibitors, } \\
\text { oral antihistamines, } \\
\text { and cyclosporine A }\end{array}$ & 3 & $\begin{array}{l}\text { Mean SCORAD improvement by } \\
38 \% \text { (week 3), 46\% (week 5), } \\
56 \% \text { (week 9), and } 59 \% \text { (week } \\
\text { 13); parallel improvement of EASI }\end{array}$ & $\begin{array}{l}\text { Temporal mean serum IgE reduction } \\
\text { by }>90 \% \text { per IA cycle (similarly for } \\
\text { IgG/lgM/lgA); sustained reduction } \\
\text { of skin-bound lgE as well as } \\
\text { histologic alterations (hyperkeratosis, } \\
\text { spongiosis, acanthosis, and dermal } \\
\text { infiltrate) }\end{array}$ & $\begin{array}{l}\text { Central venous catheter- } \\
\text { related Staphylococcus } \\
\text { aureus septicemia }(n=1)\end{array}$ \\
\hline $\begin{array}{l}\text { Kasperkiewicz } \\
\text { et al. (5) }\end{array}$ & $\begin{array}{l}2 \text { male patients; 40-60 years; } \\
\text { SCORAD } 66 \text { and } 77 \text { (mean } \\
\text { 71.5); total serum IgE 17,020 } \\
\text { and 46,540, (mean 31,780) kU/L, } \\
\text { respectively }\end{array}$ & $\begin{array}{l}2 \text { cycles of } 5 \text { consecutive IgE- } \\
\text { selective IA (TheraSorb-lgE } \\
\text { Miltenyi Biotec) at weeks } 1 \\
\text { and } 5\end{array}$ & $\begin{array}{l}\text { Topical corticosteroids/ } \\
\text { calcineurin inhibitors, } \\
\text { oral antihistamines, } \\
\text { and cyclosporine A }\end{array}$ & 6 & $\begin{array}{l}\text { Mean SCORAD improvement by } \\
33 \% \text { (week 3), 37\% (week 5), } \\
54 \% \text { (week 9), 53\% (week 13), } \\
\text { 55\% (week 17), and 49\% } \\
\text { (week 25) }\end{array}$ & $\begin{array}{l}\text { Temporal mean serum IgE } \\
\text { reduction by }>90 \% \text { per IA } \\
\text { cycle ( } 36-49 \% \text { for } \\
\text { lgG/IgM/lgA) }\end{array}$ & None \\
\hline $\begin{array}{l}\text { Daeschlein } \\
\text { et al. (6) }\end{array}$ & $\begin{array}{l}7 \text { patients, } 2 \text { females and } 5 \\
\text { males; 17-61 (mean 35.3) years; } \\
\text { SCORAD 21.3-77 (mean 52); } \\
\text { total serum IgE } 724-28,500 \\
\text { (mean 11,015) kU/L }\end{array}$ & $\begin{array}{l}\text { 1-5 cycles of } 5 \text { consecutive } \\
\text { panimmunoglobulin IA } \\
\text { (TheraSorb-lg flex , Miltenyi } \\
\text { Biotec) at monthly intervals }\end{array}$ & $\begin{array}{l}\text { Topical corticosteroids/ } \\
\text { calcineurin inhibitors, } \\
\text { oral antihistamines, } \\
\text { cyclosporine A }\end{array}$ & $12-18$ & $\begin{array}{l}\text { Mean SCORAD improvement by } \\
25.1 \% \text { (after } 1 . \text { IA cycle), } 27.9 \% \\
\text { (after 2. IA cycle), 37.6\% (after } 3 . \\
\text { IA cycle), } 24.1 \% \text { (after } 4 . \text { IA cycle), } \\
\text { and } 11.1 \% \text { (after 5. IA cycle) }\end{array}$ & $\begin{array}{l}\text { Temporal mean serum lgE } \\
\text { reduction by } 74-80 \% \text { per } \\
\text { IA cycle }\end{array}$ & Drop of blood pressure $(n=2)$ \\
\hline Zink et al. (7) & $\begin{array}{l}10 \text { patients, } 2 \text { females and } 8 \\
\text { males; 26-65 (mean 43.7) years; } \\
\text { SCORAD 50.2-74.6 (mean 59.9); } \\
\text { total serum IgE 3,728-69,872 } \\
\text { (mean 18,094) kU/L }\end{array}$ & $\begin{array}{l}1 \text { cycle of } 2-4 \text { consecutive } \\
\text { panimmunoglobulin IA } \\
\text { (TheraSorb-lg flex }{ }^{\otimes} \text {, Miltenyi } \\
\text { Biotec) followed by omalizumab } \\
\text { every } 2 \text { weeks for } 24 \text { weeks }\end{array}$ & $\begin{array}{l}\text { Topical } \\
\text { corticosteroids }\end{array}$ & 12 & $\begin{array}{l}\text { Mean SCORAD improvement } \\
\text { by } 27 \% \text { (week 3), 40\% (week } \\
\text { 13), } 55 \% \text { (week 25), and 19\% } \\
\text { (re-increased; week 49); parallel } \\
\text { improvement and re-increase of } \\
\text { VAS subjective severity score }\end{array}$ & $\begin{array}{l}\text { Mean serum IgE reduction by } \\
58-86 \% \text { after } 2-4 \text { IA, respectively; } \\
\text { serum IgE and TARC levels } \\
\text { decreased continuously during } \\
\text { omalizumab therapy and } \\
\text { re-increased during } \\
\text { treatment-free follow-up }\end{array}$ & $\begin{array}{l}\text { IA-related: dizziness } \\
(n=1) \text { and fatigue }(n=2) \text {; } \\
\text { omalizumab-related: } \\
\text { headache }(n=1) \text {, abdominal } \\
\text { pain }(n=1) \text {, axillary lymph } \\
\text { node swelling }(n=1) \text {, and } \\
\text { elevation of liver enzymes } \\
(n=3)\end{array}$ \\
\hline $\begin{array}{l}\text { Reich } \\
\text { et al. (8) }\end{array}$ & $\begin{array}{l}50 \text { patients, } 20 \text { females and } 30 \\
\text { males; } 21-75 \text { (mean } 45.6 \text { ) years; } \\
\text { mean EASI and SCORAD } 21.3 \\
\text { and } 40.5 \text {, respectively; median } \\
\text { total serum IgE 6,700 k }\end{array}$ & $\begin{array}{l}3 \text { cycles of } 3-4 \text { consecutive } \\
\text { panimmunoglobulin IA ( } n=24 ; \\
\text { TheraSorb-Ig flex }{ }^{\oplus} \text {, Miltenyi } \\
\text { Biotec) or IgE-selective IA } \\
(n=26 \text {; TheraSorb-lgE } \\
\text { Miltenyi Biotec) at weeks } \\
1,3, \text { and } 8\end{array}$ & $\begin{array}{l}\text { Topical and systemic } \\
\text { corticosteroids, topical } \\
\text { calcineurin inhibitors, } \\
\text { cyclosporine A, } \\
\text { methotrexate, and } \\
\text { mycophenolate mofetil }\end{array}$ & 8 & $\begin{array}{l}\text { Median EASl improvement by } 39 \\
\text { and } 47 \% \text { (week 6), } 52 \text { and } 45 \% \\
\text { (week 12), and } 61 \text { and } 60 \% \text { (week } \\
\text { 32) in the panimmunoglobulin and } \\
\text { lgE-selective IA group, respectively; } \\
\text { parallel improvement of SCORAD, } \\
\text { POEM, and DLQI }\end{array}$ & $\begin{array}{l}\text { Temporal median serum } \\
\text { IgE reduction by } 85 \text { and } 90 \% \text { per IA } \\
\text { cycle in the panimmunoglobulin and } \\
\text { IgE-selective IA group ( } 85 \text { and } \\
20 \% \text { for lgG), respectively }\end{array}$ & $\begin{array}{l}\text { Panimmunoglobulin IA } \\
\text { group only: herpes labialis } \\
(n=2) \text {, herpes keratitis } \\
(n=1) \text {, bacterial conjunctivitis } \\
(n=1) \text {, bacterial sinusitis } \\
(n=1) \text {, air embolism during } \\
\text { central venous catheter } \\
\text { placement }(n=1) \text {, cubital vein } \\
\text { thrombophlebitis }(n=1) \text {, and } \\
\text { generalized cutaneous allergic } \\
\text { drug reaction }(n=1)\end{array}$ \\
\hline $\begin{array}{l}\text { Kasperkiewicz } \\
\text { et al. (9) }\end{array}$ & $\begin{array}{l}10 \text { patients, } 3 \text { females and } 7 \\
\text { males; } 18-70 \text { (mean 40.3) years; } \\
\text { SCORAD 61.5-81 (mean 67.5); } \\
\text { total IgE 931-21,510 (mean } \\
5,377 \text { ) kU/L }\end{array}$ & $\begin{array}{l}2 \text { cycles of } 5 \text { consecutive IgE- } \\
\text { selective IA (TheraSorb-IgE }{ }^{\oplus} \text {; } \\
\text { Miltenyi Biotec) at weeks } 1 \\
\text { and } 5\end{array}$ & $\begin{array}{l}\text { Topical and systemic } \\
\text { corticosteroids, topical } \\
\text { calcineurin inhibitors, } \\
\text { oral antihistamines }\end{array}$ & 6 & $\begin{array}{l}\text { Mean SCORAD improvement by } \\
19 \% \text { (week 3), 29\% (week 5), } \\
43 \% \text { (week 9), 21\% (week 13), } \\
\text { 25\% (week 17), and } \\
29 \% \text { (week 25) }\end{array}$ & $\begin{array}{l}\text { Temporal mean serum IgE } \\
\text { reduction by }>90 \% \text { per IA } \\
\text { cycle (35-43\% for } \\
\text { IgG/IgM/lgA) }\end{array}$ & $\begin{array}{l}\text { Central venous catheter- } \\
\text { related } S \text {. aureus septicemia } \\
(n=1) \text {, fatigue }(n=1) \text {, and } \\
\text { edema of hands and feet } \\
(n=1)\end{array}$ \\
\hline
\end{tabular}

AD, atopic dermatitis; DLQI, Dermatology Life Quality Index; EASI, Eczema Area and Severity Index; IA, immunoadsorption; POEM, Patient-Oriented Eczema Measure; SCORAD, Scoring Atopic Dermatitis; TARC, thymus and activation regulated chemokine; VAS, Visual Analog Scale. 


\section{Effects on Skin-bound IgE and Other Skin Parameters}

In contrast to the abovementioned kinetics of circulating IgE, a continuous reduction of the amount of skin-bound IgE was observed by immunohistochemistry in our initial IA pilot study (4). It can be hypothesized that a redistribution of tissue-bound IgE from inflammatory skin sites into the intravascular compartment occurs, which may at least partly explain the rebound phenomenon of serum IgE levels following IA. In addition, repetitive skin biopsies after IA revealed a steady decrease in skin infiltration by antigen-presenting cells and $\mathrm{T}$ cell as well as improvement of altered epidermal morphology including hyperkeratosis, spongiosis, and acanthosis (4). In this context, it is worth noting that omalizumab has been previously shown to inhibit antigen processing and presentation to $\mathrm{T}$ cells by downregulating the expression of the high-affinity $\operatorname{IgE}$ receptor FcepsilonRI on dendritic cells (14). Thus, impairment of IgEmediated antigen exposure in the skin could represent a possible mechanism of action of IA contributing to disease amelioration in $\mathrm{AD}$ patients.

\section{Safety}

IA in patients with $\mathrm{AD}$, who usually have an increased genetic susceptibility to skin infections by pathogens such as Staphylococcus aureus and Herpes simplex virus (1), is generally well tolerated (4-9). The selective IgE adsorber has been developed to decrease the potential higher risk of infections due to the parallel considerable reduction of protective immunoglobulins as it occurs with panimmunoglobulin IA. In fact, in the study by Reich et al., infectious adverse events, including bacterial conjunctivitis/ sinusitis and herpes labialis/keratitis, were observed in $\mathrm{AD}$ patients treated by panimmunoglobulin IA but not IgE-selective IA (8). By contrast, however, we reported two cases of $S$. aureus septicemia, one occurring after panimmunoglobulin IA and the other following IgE-selective IA, both performed by a central venous catheter $(4,9)$. Thus, IgE-selective IA using peripheral venous access seems most preferable, although further studies are needed to better define the safety profile of this treatment in $\mathrm{AD}$ patients.

\section{Autoreactive IgE as Potential Target of IA in AD}

With the help of Th2 cytokines, activated B cells undergo production of IgE antibodies, which have been reported to be partly of the autoreactive type in AD (15-18). More than 140 autoantigens triggering $\operatorname{IgE}$ autoantibodies in $\mathrm{AD}$ patients have been reported (16), some of them potentially binding to cell membrane and intracellular structures of cultured human keratinocytes (15). IgE autoantibodies can either be specific for autoantigens (Homs 1-5, antinuclear antibodies, DSF70, and p80-coilin) or cross-react with environmental allergens due to their high homology with self-antigens (manganese superoxide dismutase, thioredoxin, profilin, and acidic ribosomal P2 protein) (18). In fact, a systematic review involving 1,253 AD patients and 1,391 control subjects found autoreactivity in up to $91 \%$ compared with $0-12 \%$, respectively, although it remains widely unknown whether this is a cause or consequence of skin inflammation in AD (17).

It has been hypothesized that scratching-induced tissue damage can lead to the release of autoantigens that bind to $\operatorname{IgE}$ autoantibodies. This may consecutively result in immediatetype hypersensitivity reactions as well as $\mathrm{T}$ cell activation and cytokine secretion through IgE cross-linking on the cell surface and IgE-mediated autoantigen presentation, respectively (18). In contrast to other IgE-driven diseases, such as bullous pemphigoid (19), however, it is less known whether autoreactive IgE in $\mathrm{AD}$ patients are truly pathogenic or only represent a bystander epiphenomenon.

Pathogenicity of IgE-mediated autoreactivity in $\mathrm{AD}$ is supported by the following reported evidence: (i) IgE autoantibodies are not present in other allergic diseases, such as allergic asthma or allergic rhinoconjunctivitis, which are characterized by increased total IgE levels (17); (ii) existence of pro-inflammatory cytokine-producing autoreactive $\mathrm{T}$ cells specific for autoantigens [e.g., $\alpha$-NAC (Homs 2)] for which autoreactivity has been described on the humoral level $(20,21)$; (iii) disease severity in $\mathrm{AD}$ patients is higher in autoreactive patients than in non-autoreactive ones $(15,17)$; (iv) SCORAD values and serum TARC levels correlate with IgE autoantibodies to human manganese superoxide dismutase and DSF70, respectively $(22,23)$; and (v) cyclosporine A-induced improvement of skin symptoms in AD patients is accompanied by reduction in $\operatorname{IgE}$ autoreactivity (but not IgE antibodies to exogenous allergens), with a reverse trend without treatment; clinical improvement precedes decrease of IgE autoreactivity, potentially suggesting reduced tissue injurydriven exposure of self-antigens to autoreactive B cells in these patients $(24,25)$.

Therefore, it is tempting to speculate that disease amelioration by IA in some AD patients may also, at least in part, be attributed to a decrease of $\operatorname{IgE}$ autoreactivity.

\section{CONCLUSION}

Clinical evidence suggests that IA seems to be an effective treatment option for patients severely affected by $\mathrm{AD}$ with highly elevated IgE serum levels. IA is associated with temporal and sustained reduction of circulating and skin-bound IgE, but the exact mechanisms underlying the clinical response in $\mathrm{AD}$ patients remain to be elucidated (4-9). Although the role of $\operatorname{IgE}$ in $\mathrm{AD}$ is still a matter of debate, these findings favor a pathogenic potential of IgE antibodies in this disorder. Future studies should explore whether a particular subset of $\mathrm{AD}$ patients who have circulating autoreactive $\operatorname{IgE}$ antibodies may especially benefit from this type of direct antibody depletion therapy.

\section{AUTHOR CONTRIBUTIONS}

MK wrote the paper with the help of ES, RL, and DZ.

\section{FUNDING}

This work was supported by infrastructural funding provided by Deutsche Forschungsgemeinschaft Excellence Cluster Inflammation at Interfaces (EXC 306/2). 


\section{REFERENCES}

1. Weidinger S, Novak N. Atopic dermatitis. Lancet (2016) 387:1109-22. doi:10.1016/S0140-6736(15)00149-X

2. Wang HH, Li YC, Huang YC. Efficacy of omalizumab in patients with atopic dermatitis: a systematic review and meta-analysis. J Allergy Clin Immunol (2016) 138:1719-22. doi:10.1016/j.jaci.2016.05.038

3. Kornmann O, Watz H, Fuhr R, Krug N, Erpenbeck VJ, Kaiser G. Omalizumab in patients with allergic (IgE-mediated) asthma and IgE/bodyweight combinations above those in the initially approved dosing table. Pulm Pharmacol Ther (2014) 28:149-53. doi:10.1016/j.pupt.2014.03.003

4. Kasperkiewicz M, Schmidt E, Frambach Y, Rose C, Meier M, Nitschke M, et al. Improvement of treatment-refractory atopic dermatitis by immunoadsorption: a pilot study. J Allergy Clin Immunol (2011) 127:267-70. doi:10.1016/j.jaci.2010.07.042

5. Kasperkiewicz M, Süfke S, Schmidt E, Zillikens D. IgE-specific immunoadsorption for treatment of recalcitrant atopic dermatitis. JAMA Dermatol (2014) 150:1350-1. doi:10.1001/jamadermatol.2014.2082

6. Daeschlein G, Scholz S, Lutze S, Eming R, Arnold A, Haase H, et al. Repetitive immunoadsorption cycles for treatment of severe atopic dermatitis. Ther Apher Dial (2015) 19:279-87. doi:10.1111/1744-9987.12267

7. Zink A, Gensbaur A, Zirbs M, Seifert F, Suarez IL, Mourantchanian V, et al. Targeting IgE in severe atopic dermatitis with a combination of immunoadsorption and omalizumab. Acta Derm Venereol (2016) 96:72-6. doi:10.2340/00015555-2165

8. Reich K, Deinzer J, Fiege AK, von Gruben V, Sack AL, Thraen A, et al. Panimmunoglobulin and IgE-selective extracorporeal immunoadsorption in patients with severe atopic dermatitis. J Allergy Clin Immunol (2016) 137:1882-4. doi:10.1016/j.jaci.2016.01.016

9. Kasperkiewicz M, Mook SC, Knuth-Rehr D, Vorobyev A, Ludwig RJ, Zillikens D, et al. IgE-selective immunoadsorption for severe atopic dermatitis. Front Med (2018) 5:27. doi:10.3389/fmed.2018.00027

10. Dahdah L, Ceccarelli S, Amednola S, Campagnano P, Cancrini C, Mazzina O. IgE immunoadsorption knocks down the risk of food-related anaphylaxis. Pediatrics (2015) 136:e1617-20. doi:10.1542/peds.2015-1757

11. Dahdah L, Leone G, Artesani M, Raccardi C, Mazzina O. Apheresis in food allergies. Curr Opin Allergy Clin Immunol (2017) 17:227-31. doi:10.1097/ ACI.0000000000000366

12. Lupinek C, Derfler K, Lee S, Prikoszovich T, Movadat O, Wollmann E, et al. Extracorporeal IgE immunoadsorption in allergic asthma: safety and efficacy. EBioMedicine (2017) 17:119-33. doi:10.1016/j.ebiom.2017. 02.007

13. Meyersburg D, Schmidt E, Kasperkiewicz M, Zillikens D. Immunoadsorption in dermatology. Ther Apher Dial (2012) 16:311-20. doi:10.1111/j.17449987.2012.01075.x

14. Prussin C, Griffith DT, Boesel KM, Lin H, Foster B, Casale TB. Omalizumab treatment downregulates dendritic cell FcepsilonRI expression. J Allergy Clin Immunol (2003) 112:1147-54. doi:10.1016/j.jaci.2003. 10.003
15. Altrichter S, Kriehuber E, Moser J, Valenta R, Kopp T, Stingl G. Serum IgE autoantibodies target keratinocytes in patients with atopic dermatitis. J Invest Dermatol (2008) 128:2232-9. doi:10.1038/jid.2008.80

16. Zeller S, Rhyner C, Meyer N, Schmid-Grendelmeier P, Akdis CA, Crameri R. Exploring the repertoire of IgE-binding self-antigens associated with atopic eczema. J Allergy Clin Immunol (2009) 124: 278-85, 285.e1-7. doi:10.1016/j.jaci.2009.05.015

17. Tang TS, Bieber T, Williams HC. Does "autoreactivity" play a role in atopic dermatitis? J Allergy Clin Immunol (2012) 129: 1209-15.e2. doi:10.1016/j. jaci.2012.02.002

18. Hradetzky S, Werfel T, Rösner LM. Autoallergy in atopic dermatitis. Allergo J Int (2015) 24:16-22. doi:10.1007/s40629-015-0037-5

19. van Beek N, Schulze FS, Zillikens D, Schmidt E. IgE-mediated mechanisms in bullous pemphigoid and other autoimmune bullous diseases. Expert Rev Clin Immunol (2016) 12:267-77. doi:10.1586/1744666X.2016.1123092

20. Heratizadeh A, Mittermann I, Balaji H, Wichmann K, Niebuhr M, Valenta R, et al. The role of T-cell reactivity towards the autoantigen $\alpha$-NAC in atopic dermatitis. Br J Dermatol (2011) 164:316-24. doi:10.1111/j.1365-2133. 2010.10090.x

21. Roesner LM, Heratizadeh A, Wieschowski S, Mittermann I, Valenta R, Eiz-Vesper B, et al. $\alpha$-NAC-specific autoreactive CD8+ T cells in atopic dermatitis are of an effector memory type and secrete IL-4 and IFN- $\gamma$. J Immunol (2016) 196:3245-52. doi:10.4049/jimmunol.1500351

22. Schmid-Grendelmeier P, Flückiger S, Disch R, Trautmann A, Wüthrich B, Blaser $\mathrm{K}$, et al. IgE-mediated and $\mathrm{T}$ cell-mediated autoimmunity against manganese superoxide dismutase in atopic dermatitis. J Allergy Clin Immunol (2005) 115:1068-75. doi:10.1016/j.jaci.2005.01.065

23. Watanabe K, Muro Y, Sugiura K, Tomita Y. IgE and IgG(4) autoantibodies against DFS70/LEDGF in atopic dermatitis. Autoimmunity (2011) 44:511-9. doi:10.3109/08916934.2010.549157

24. Kinaciyan T, Natter S, Kraft D, Stingl G, Valenta R. IgE autoantibodies monitored in a patient with atopic dermatitis under cyclosporin A treatment reflect tissue damage. J Allergy Clin Immunol (2002) 109:717-9. doi:10.1067/mai.2002.123303

25. Lucae S, Schmid-Grendelmeier P, Wüthrich B, Kraft D, Valenta R, Linhart B. $\mathrm{IgE}$ responses to exogenous and endogenous allergens in atopic dermatitis patients under long-term systemic cyclosporine A treatment. Allergy (2016) 71:115-8. doi:10.1111/all.12711

Conflict of Interest Statement: All authors have a research cooperation with Miltenyi Biotec. The authors declare that the research was conducted in the absence of any commercial or financial relationships that could be construed as a potential conflict of interest.

Copyright (c) 2018 Kasperkiewicz, Schmidt, Ludwig and Zillikens. This is an openaccess article distributed under the terms of the Creative Commons Attribution License (CC BY). The use, distribution or reproduction in other forums is permitted, provided the original author(s) and the copyright owner are credited and that the original publication in this journal is cited, in accordance with accepted academic practice. No use, distribution or reproduction is permitted which does not comply with these terms. 